\title{
Paris Polyphylla Inhibits Colorectal Cancer Cells via Inducing Autophagy and Enhancing the Efficacy of Chemotherapeutic Drug Doxorubicin
}

\author{
Liang-Tzung Lin ${ }^{1,2}$, Wu-Ching Uen ${ }^{3,4}$, Chen-Yen Choong ${ }^{5}$, Yeu-Ching Shi ${ }^{5} \oplus$, Bao-Hong Lee ${ }^{5}$, \\ Cheng-Jeng Tai ${ }^{5,6}$ and Chen-Jei Tai ${ }^{7,8,9, *}$ \\ 1 Department of Microbiology and Immunology, School of Medicine, College of Medicine, \\ Taipei Medical University, Taipei 11042, Taiwan; 1tlin@tmu.edu.tw \\ 2 Graduate Institute of Medical Sciences, College of Medicine, Taipei Medical University, Taipei 11042, Taiwan \\ 3 School of Medicine, Fujen Catholic University, New Taipei City 24205, Taiwan; m002047@ms.skh.org.tw \\ 4 Department of Hematology and Oncology, Shin Kong Wu Ho-Su Memorial Hospital, Taipei 11042, Taiwan \\ 5 Division of Hematology and Oncology, Department of Internal Medicine, Taipei Medicine University \\ Hospital, Taipei 11042, Taiwan; chenyen@tmu.edu.tw (C.-Y.C.); jasmineycs@yahoo.com.tw (Y.-C.S.); \\ f96b47117@ntu.edu.tw (B.-H.L.); cjtai@tmu.edu.tw (C.-J.T.) \\ 6 Division of Hematology and Oncology, Department of Internal Medicine, School of Medicine, \\ College of Medicine, Taipei Medical University, Taipei 11042, Taiwan \\ 7 Department of Chinese Medicine, Taipei University Hospital, Taipei 11042, Taiwan \\ 8 Traditional Herbal Medicine Research Center, Taipei Medical University Hospital, Taipei 11042, Taiwan \\ 9 Department of Obstetrics and Gynecology, School of Medicine, College of Medicine, Taipei Medical \\ University, Taipei 11042, Taiwan \\ * Correspondence: chenjtai@tmu.edu.tw; Tel.: +886-02-27372181-3903; Fax: +886-02-2736-3051
}

Academic Editor: Roberto Fabiani

Received: 1 May 2019; Accepted: 31 May 2019; Published: 3 June 2019

\begin{abstract}
Colorectal cancer is one of the most common cancers worldwide and chemotherapy is the main approach for the treatment of advanced and recurrent cases. Developing an effective complementary therapy could help to improve tumor suppression efficiency and control adverse effects from chemotherapy. Paris polyphylla is a folk medicine for treating various forms of cancer, but its effect on colorectal cancer is largely unexplored. The aim of the present study is to investigate the tumor suppression efficacy and the mechanism of action of the ethanolic extract from P. polyphylla (EEPP) in DLD-1 human colorectal carcinoma cells and to evaluate its combined effect with chemotherapeutic drug doxorubicin. The data indicated that EEPP induced DLD-1 cell death via the upregulation of the autophagy markers, without triggering p53- and caspase-3-dependent apoptosis. Moreover, EEPP treatment in combination with doxorubicin enhanced cytotoxicity in these tumor cells. Pennogenin 3-O-beta-chacotrioside and polyphyllin VI were isolated from EEPP and identified as the main candidate active components. Our results suggest that EEPP deserves further evaluation for development as complementary chemotherapy for colorectal cancer.
\end{abstract}

Keywords: folk medicine; DLD-1 cells; doxorubicin; chemotherapy; drug resistance

\section{Introduction}

Paris polyphylla is a well-known herbal medicine used in China and Taiwan, primarily to treat fevers, headaches, burns, and wounds, and for neutralizing snake poison [1]. The plant extract was documented to exert anti-cancer activity both in vivo and in vitro [2]. Numerous natural steroidal saponins isolated from herbs show potential apoptosis-promoting activity against several cancer cells types [3-5]. In addition, P. polyphylla treatment can inhibit epithelial-mesenchymal transition (EMT) 
and invasion in breast cancer [6] and lung cancer cells [3-5]. Recently, P. polyphylla extract was also found to inhibit ovarian carcinoma cell growth [7].

The use of complementary and alternative medicine is now a very popular option to support conventional therapy in many countries [8-10]. For example, many herbal formulas and remedies based on traditional Chinese medicine are well accepted among cancer patients with Chinese background [11-13]. Traditional Chinese medicine (TCM) is based on the use of natural products and well-established theoretical approaches. TCM provides many potential candidates as effective drugs for integrated cancer chemotherapy, such as TJ-41 (Bu-Zhong-Yi-Qi-Tang) and PHY906 (Huang-Qin-Tang) [11,12]. In TCM practice, a therapeutic formula is normally prepared as an aqueous extract mixed with various medical herbs. One major herb in this formula is responsible for relieving the target symptom, whereas other medicinal herbs are added to enhance the therapeutic effects or reduce the side effects of the major herb [13].

Colorectal cancer is one of the most common cancer types worldwide with particularly high incidences in developed countries [14]. In Taiwan, colorectal cancer is the most common type of cancer and the third most common cause of cancer-related deaths [15]. Currently, surgery is still the only curative treatment for colorectal cancer. Although $75-80 \%$ of newly diagnosed cases are localized or regional tumors, around 50\% of patients suffer recurrence after surgery [16,17]. Adjuvant therapy such as postoperative chemotherapy is used to eliminate remaining lesions and help control the risk of recurrence. Chemotherapy is also one of the main treatment approaches in advanced and recurrent cases while often associated with adverse side effects in patients, particularly in the elderly population $[12,13]$. Various drug resistance problems in colorectal cancer cases also reduce the response rates. These clinical features limit the use of chemotherapy in patients. Any effective drug which promotes the tumor suppression efficacy of chemotherapeutic regimens or eases the associated adverse effects may serve as an appropriate candidate to establish integrated chemotherapy and improve clinical outcomes in cancer patients. Combining standard chemotherapeutics with antitumor drugs to induce tumor cell death via other molecular pathways would not only improve tumor suppression efficiency but also reduce the doses of chemotherapeutic drugs, which could help control adverse effects and may slow the development of drug resistance. Due to the use of chemotherapy as the main approach for advanced and recurrent cancers, developing effective complementary drugs could help improve tumor suppression efficiency and control adverse effects from chemotherapy. DLD-1 is a colorectal adenocarcinoma cell line similar to HT-29 and Caco-2 cell lines [16], which are established from tumorigenic epithelial tissue. In this study, we investigated the effect of the ethanolic extracts of P. polyphylla (EEPP) on the suppression of DLD-1 colorectal carcinoma cells with or without chemotherapeutic drug (doxorubicin) treatment.

\section{Results and Discussion}

\subsection{Treatment Effect of P. polyphylla on Colorectal Cancer Cell Growth}

As shown in Figure 1A, compared to the untreated group, cell viability of DLD-1 colorectal carcinoma cells were decreased after treatment with 3.13-50 $\mu \mathrm{g} / \mathrm{mL}$ EEPP for 24 or $48 \mathrm{~h}$ in a dose-dependent manner. On the other hand, the aqueous extract of $P$. polyphylla (AEPP) required higher doses to inhibit the growth of colorectal cancer cells. In addition, EEPP treatment, particularly at $6.25 \mu \mathrm{g} / \mathrm{mL}$, induced apparent morphological alterations in the DLD-1 cells compared to the untreated group (Figure 1B). These results indicate that EEPP treatment induced cytotoxicity in colorectal carcinoma cells, suggesting that EEPP treatment causes DLD-1 colorectal cancer cell death. 

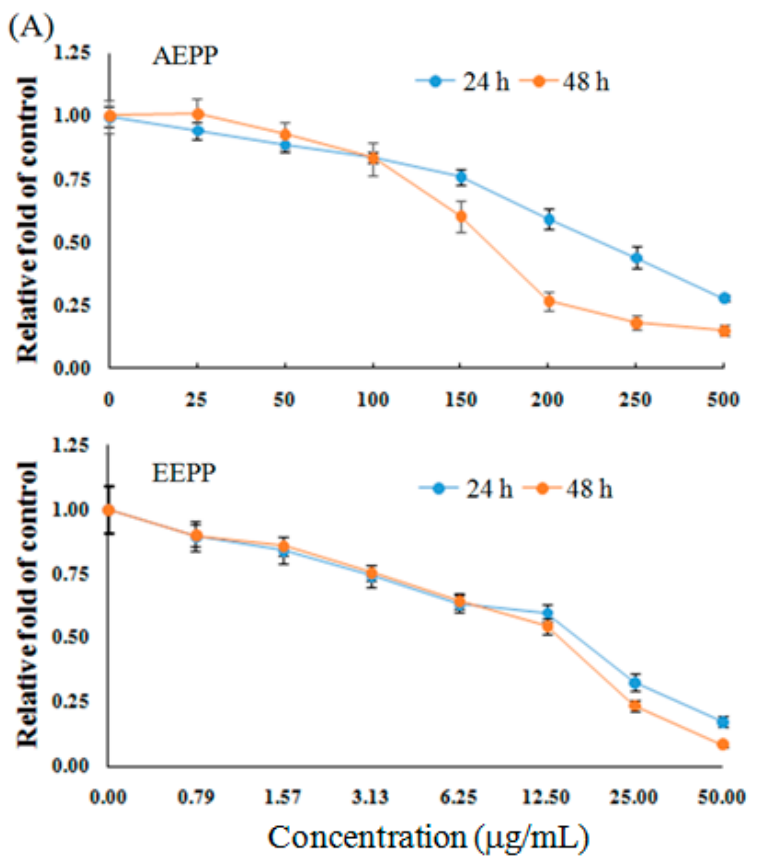

(B)

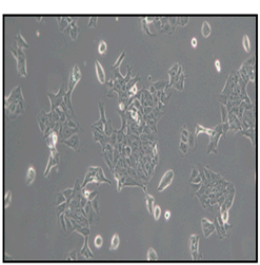

$0 \mu \mathrm{g} / \mathrm{mL}$

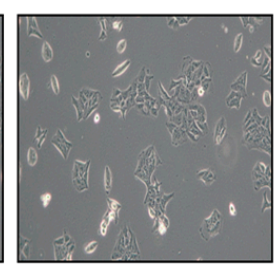

$3.13 \mu \mathrm{g} / \mathrm{mL}$

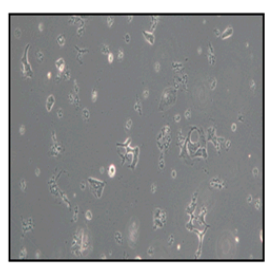

$6.25 \mu \mathrm{g} / \mathrm{mL}$

Figure 1. Inhibitory effect of Paris polyphylla on colorectal cancer cells. (A) Inhibitory effect of aqueous extract of $P$. polyphylla (AEPP) or ethanolic extract of $P$. polyphylla (EEPP) on DLD-1 colorectal carcinoma cells after treatment for 24 and $48 \mathrm{~h}$, respectively. Data are shown as means $\pm \operatorname{SD}(n=3)$.

(B) The morphological appearance of DLD-1 colorectal carcinoma cells after $24 \mathrm{~h}$ of EEPP treatment.

One approach in developing integrated chemotherapy is to choose a drug which enhances tumor cell suppression efficiency by increasing cytotoxicity using a different cell death mechanism from the other drugs used in the regimen. In general, the tumor suppression mechanisms of current chemotherapeutic drugs are mainly based on disruption of cell-cycle processes, resulting in cell apoptosis. Next, we sought to examine the possible mechanism through which EEPP causes DLD-1 colorectal cancer cell death. To this end, we examined the effect of EEPP treatment on cell-cycle regulation in the DLD-1 cells. As indicated in Figure 2A, treatment of the DLD-1 cells with 3.13-13.5 $\mu \mathrm{g} / \mathrm{mL}$ EEPP for $12 \mathrm{~h}$ demonstrated a similar cell-cycle distribution pattern to the control group, suggesting that EEPP does not disrupt the cell-cycle progression in the DLD-1 colorectal cancer cells. To further determine the cell death pathway involved in EEPP-induced colorectal carcinoma cytotoxicity, we tested for DNA fragmentation associated with apoptosis. As indicated in Figure 2B, EEPP treatment did not induce DNA fragmentation in the DLD-1 cells. Together, these results suggest that the EEPP-mediated inhibition of the DLD-1 colorectal cancer cell growth does not involve apoptosis. 
(A)

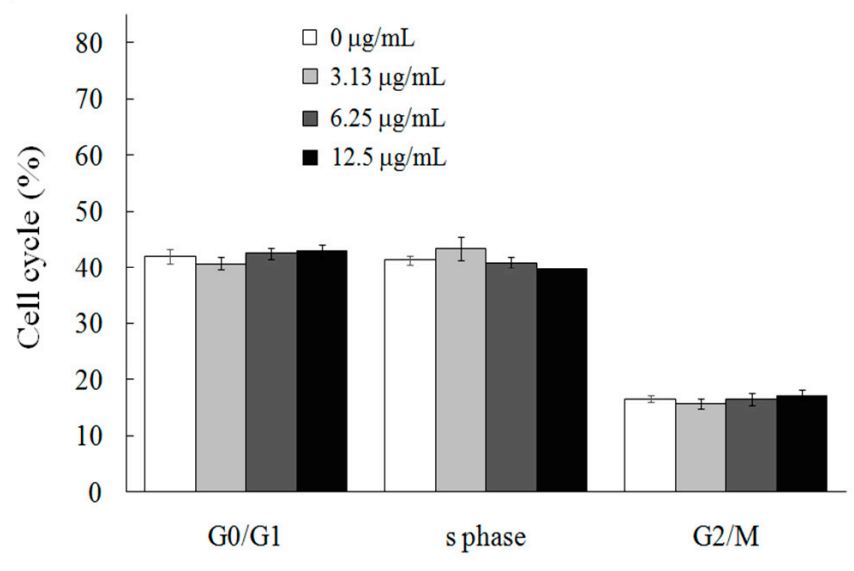

(B)

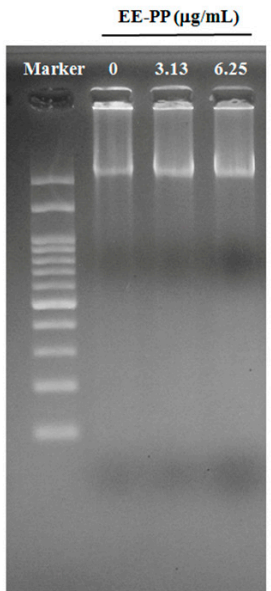

Figure 2. No effects of EEPP on (A) cell-cycle distribution and (B) DNA ladder in DLD-1 colorectal carcinoma cells. Data are shown as means $\pm \operatorname{SD}(n=3)$.

\subsection{EEPP Treatment Causes Autophagic Cell Death in Colorectal Carcinoma Cells}

Apart from apoptosis, autophagy also plays crucial roles in cancer cell survival and death, and is gaining increasing interest in cancer research. Autophagy, also termed type II programmed cell death (PCD), is a physiologic process that allows sequestration and degradation of the cytoplasmic contents through the lysosomal machinery [18]. Autophagy allows recycling of cellular components and ensures cellular energy supplement during nutrition starvation, infection, and other stress conditions [19]. Several lines of studies suggest cytotoxic agents including chemotherapeutic agents induce cancer cell autophagy [20-22]. To investigate whether autophagy is implicated in the EEPP-induced DLD-1 colorectal carcinoma cell death, cells were treated with EEPP for $24 \mathrm{~h}$ for evaluating the expression levels of the autophagy-related proteins including Beclin-1, microtubule-associated protein-1 light chain-3 (LC3), and p62 (a marker for autophagic degradation) [23,24], as well as the apoptosis-associated proteins such as Bax (Bcl2-associated X protein), p53 (tumor protein p53), Akt (Protein Kinase B), and Bcl-2 (B-cell lymphoma 2). As shown in Figure 3, in contrast to the untreated control groups, autophagy markers such as LC 3 and Beclin-1 proteins were increased after treating with EEPP for $24 \mathrm{~h}$ in a dose-dependent manner (Figure 3A, E and F). On the other hand, Akt level was downregulated in EEPP-treated DLD-1 cells after $24 \mathrm{~h}$ of treatment (Figure 3A, D), whereas the expression of p62 (Figure 3A, H), and the apoptosis markers such as p53 (Figure 3A, G), Bax (Figure 3A, B), and Bcl-2 (Figure $3 \mathrm{~A}, \mathrm{C}$ ) proteins were not affected by EEPP treatment. These results indicated that EEPP treatment induced autophagic cell death in the DLD-1 cells. 

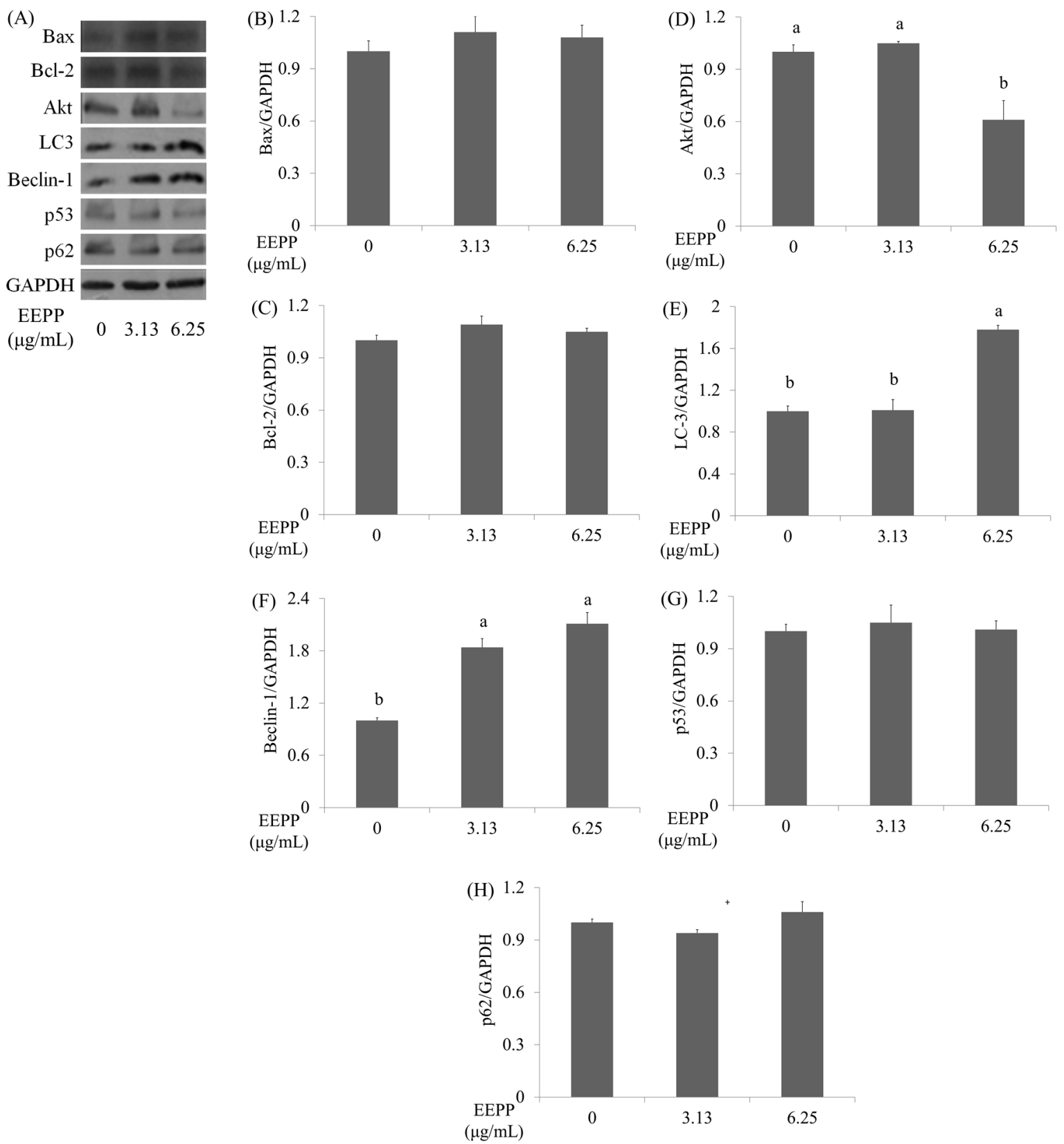

Figure 3. The effects of EEPP on apoptosis and autophagy markers. (A) The effects of EEPP on Bax, Bcl-2, Akt, LC-3, Beclin-1, p53, and p62 levels in DLD-1 colorectal carcinoma cells after $24 \mathrm{~h}$ of treatment. (B-H) Quantitative analysis for each protein levels. Data are shown as means $\pm \operatorname{SD}(n=3)$. The significant differences are denoted by different letters $(p<0.05)$.

\subsection{Effect of EEPP-Doxorubicin Combination Treatment on Autophagy Induction in Colorectal Carcinoma Cells}

Since EEPP induces autophagic cell death in DLD-1 cells, the present study further examined the potential effect of EEPP in combination with the chemotherapeutic drug doxorubicin (Dox) on DLD-1 cells. Dox functions as a topoisomerase II inhibitor and interferes with DNA/RNA synthesis in tumor cells [25]. Colorectal carcinoma cells were treated with various doses of Dox alone or in combination with EEPP for $24 \mathrm{~h}$. Figure $4 \mathrm{~A}$ illustrates that Dox treatment dose-dependently decreased cell viability in DLD-1 cells. When compared with Dox treatment alone, EEPP $(3.13 \mu \mathrm{g} / \mathrm{mL})$ combined with Dox treatment displayed stronger inhibitory activity against the DLD-1 cells, indicating that EEPP synergizes with Dox to inhibit the DLD-1 colorectal cancer cell growth. 


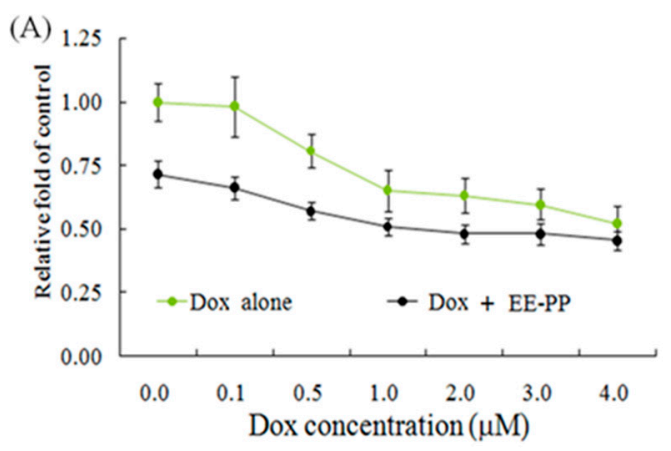

(C)

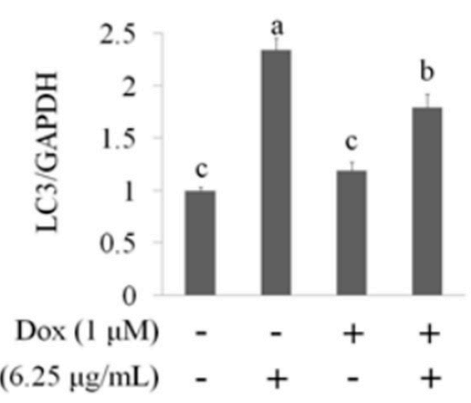

(B)

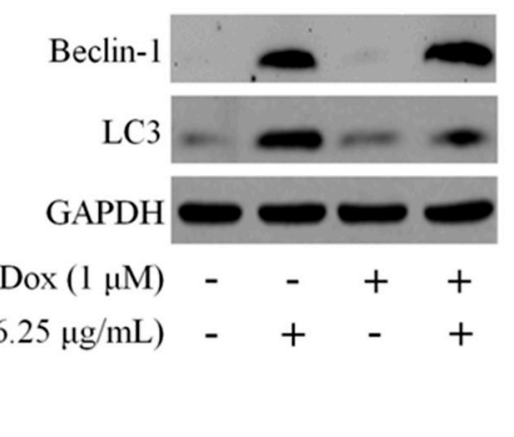

Figure 4. The combined effect of EEPP with doxorubicin (A). The suppressive effect of EEPP $(3.13 \mu \mathrm{g} / \mathrm{mL}$ ) combined with doxorubicin (Dox) for $24 \mathrm{~h}$ in DLD-1 colorectal carcinoma cells (B and C). The upregulation of Beclin-1 and LC3 expressions in EEPP-treated DLD-1 carcinoma cells. Data are shown as means $\pm \operatorname{SD}(n=3)$. The significant differences are denoted by diferent letters $(p<0.05)$.

Given that Dox is a well-known chemotherapeutic drug that induces apoptosis via the activation of p53 and caspase-3 signaling pathways in many tumor cells, we speculate that the increased cancer cell death resulting from Dox-EEPP combination treatment could be due to the potentiation of the triggered cell death pathways. To examine this hypothesis, DLD-1 cells were treated with $6.25 \mu \mathrm{g} / \mathrm{mL}$ EEPP alone, $1 \mu \mathrm{M}$ Dox alone, or Dox in combination with $6.25 \mu \mathrm{g} / \mathrm{mL}$ EEPP for $24 \mathrm{~h}$ for Western blot analysis against the apoptosis- and autophagy-related proteins. In contrast to p53 and caspase-3, whose expressions were unaltered by the combination therapy (data not shown), Dox in combination with EEPP increased both LC3 and Beclin-1 protein expressions compared to Dox alone (Figure 4B, C). This concomitant increase in autophagy markers is likely due to the presence of EEPP, which alone also upregulated the autophagy markers. Together, these results suggested that EEPP may potentially enhance the anti-tumor effect in human colorectal carcinoma cells when combined with Dox.

\subsection{Isolation and Identification of Active Compounds from EEPP}

After showing that EEPP induces autophagic cell death in DLD-1 cells, we next sought to identify the active components of the extract responsible for its cytotoxicity. We used an octadecylsilyl column to separate EEPP into five fractions by different percentages of methanol elution (Figure 5A), after which the cytotoxicity of the fractions against the DLD-1 cells was tested. Cell viability of DLD-1 colorectal carcinoma cells was decreased after treating with the $80 \%$ methanolic fraction for $24 \mathrm{~h}(0 \%$ group: survival at $78.6 \% ; 20 \%$ group: survival at $73.7 \% ; 60 \%$ group: survival at $58.1 \%$; $80 \%$ group: survival at $21.7 \% ; 100 \%$ group: survival at $38.7 \%$ ). We further isolated the active components from the $80 \%$ methanolic fraction by LC-MS and confirmed the active compounds by NMR. Pennogenin 3-O-beta-chacotrioside and polyphyllin VI were the two main compounds isolated from the $80 \%$ methanolic fraction (Figure $5 \mathrm{~B}$ ), with purity up to $95 \%$ (Figure 6). 
(A)

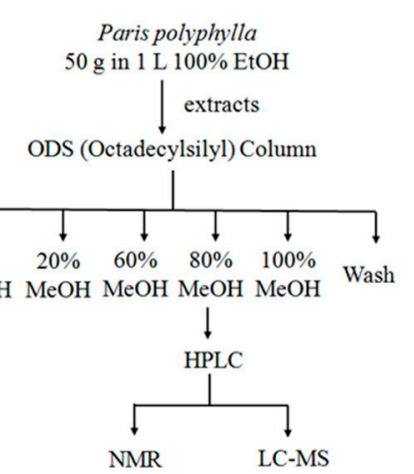

(B)

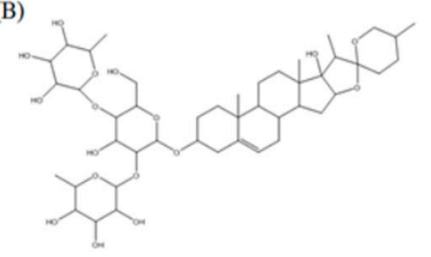

Pennogenin 3-O-beta-chacotrioside Chemical Formula: $\mathrm{C}_{45} \mathrm{H}_{72} \mathrm{O}_{17}$ Exact Mass: 884.477

Molecular Weight: 885.054

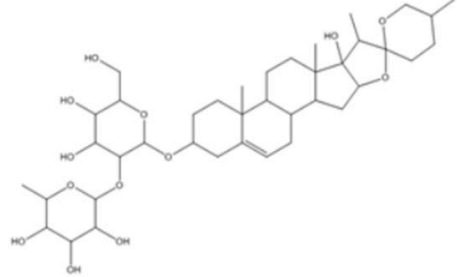

Polyphyllin VI

Chemical Formula: $\mathrm{C}_{39} \mathrm{H}_{62} \mathrm{O}_{13}$

Exact Mass: 738.419

Molecular Weight: 738.912

Figure 5. Isolation of active ingredients from EEPP. (A) The flowchart for identification of active compounds obtained from EEPP. (B) Pennogenin 3-O-beta-chacotrioside and polyphyllin VI were isolated and confirmed by NMR and LC-MS.
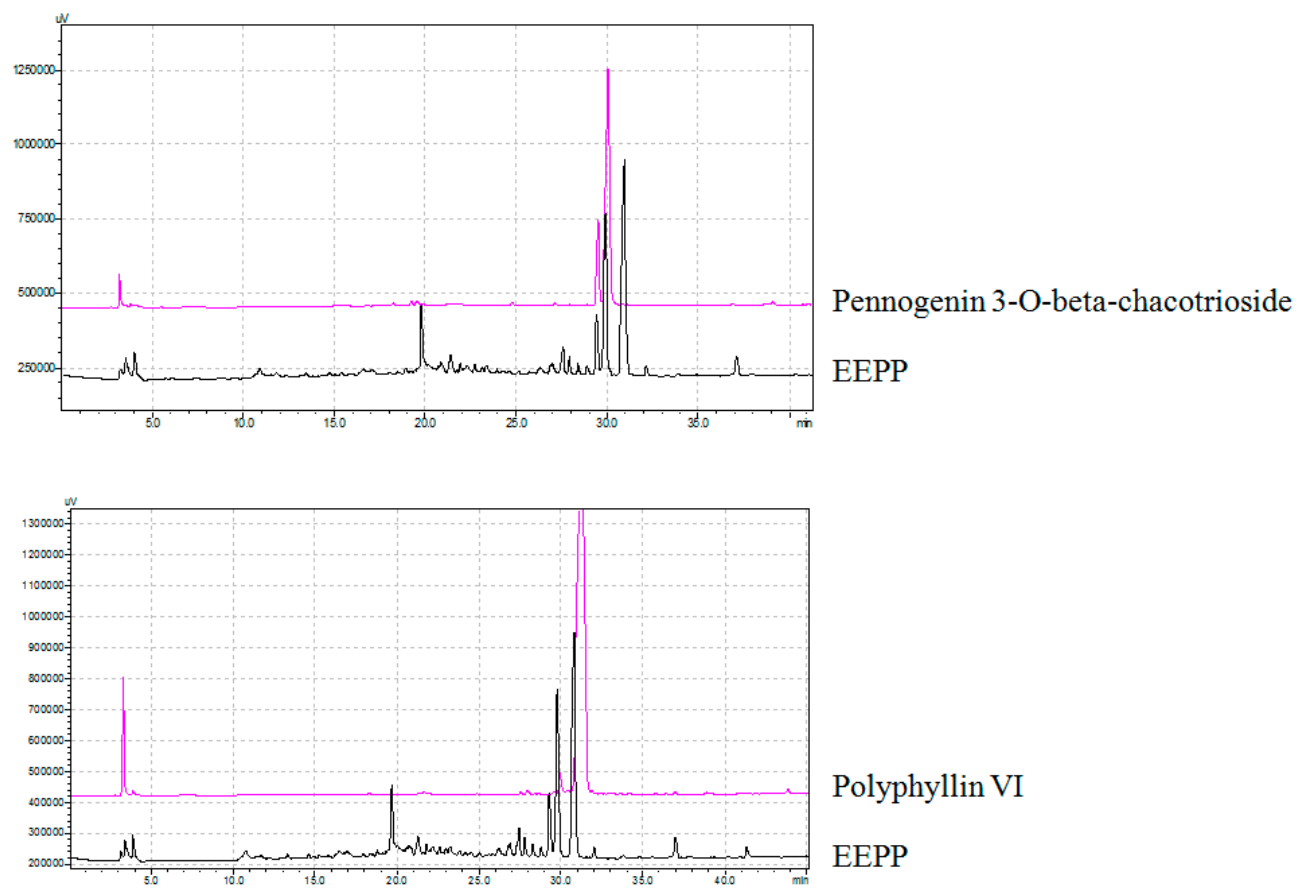

Figure 6. The purity of pennogenin 3-O-beta-chacotrioside and polyphyllin VI isolated from EEPP.

Next, the concentrations of pennogenin 3-O-beta-chacotrioside and polyphyllin VI were calculated according to EEPP, and the cell viability of DLD-1 colorectal carcinoma cells was determined. The data showed that, when compared to the untreated group, treatment of cells for $24 \mathrm{~h}$ with EEPP $(6.25 \mu \mathrm{g} / \mathrm{mL})$, pennogenin 3-O-beta-chacotrioside $(1.8 \mu \mathrm{M})$, or polyphyllin VI $(1.4 \mu \mathrm{M})$ decreased DLD-1 cell viability, indicating that pennogenin 3-O-beta-chacotrioside and polyphyllin VI are the two main active compounds from EEPP involved in colorectal cancer cell inhibition (Figure 7). 


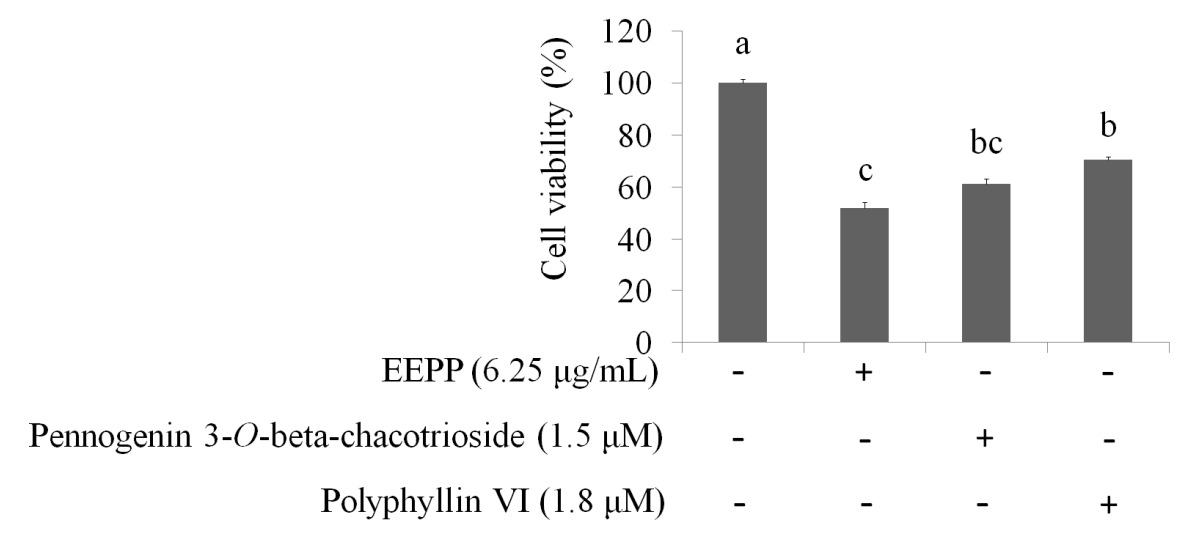

Figure 7. The suppression of DLD-1 colorectal carcinoma cells treated with EEPP $(6.25 \mu \mathrm{g} / \mathrm{mL})$, pennogenin 3-O-beta-chacotrioside $(1.8 \mu \mathrm{M})$, or polyphyllin VI $(1.4 \mu \mathrm{M})$ for $24 \mathrm{~h}$. The concentrations of pennogenin 3-O-beta-chacotrioside and polyphyllin VI were calculated according to EEPP. Data are shown as means $\pm \operatorname{SD}(n=3)$. The significant differences are denoted by different letters $(p<0.05)$.

Finally, we asked whether the active components (pennogenin 3-O-beta-chacotrioside and polyphyllin VI) could also modulate the expression of the autophagy-related proteins in the DLD-1 cells. As shown in Figure 8A,B, both pennogenin 3-O-beta-chacotrioside and polyphyllin VI treatments for $24 \mathrm{~h}$ markedly increased the expressions of LC3 and Beclin-1, suggesting that these compounds, similar to EEPP, also inhibit colorectal cancer cell death by modulating autophagy. In conclusion, our results suggest that EEPP deserves further evaluation for development as complementary chemotherapy for colorectal cancer, and pennogenin 3-O- $\beta$-chacotrioside and polyphyllin VI identified as the main candidate active components in EEPP. Schematics of the mode of action of Paris polyphylla ethanol extract on DLD-1 colorectal cancer cells is shown in Figure 9. 
(A)

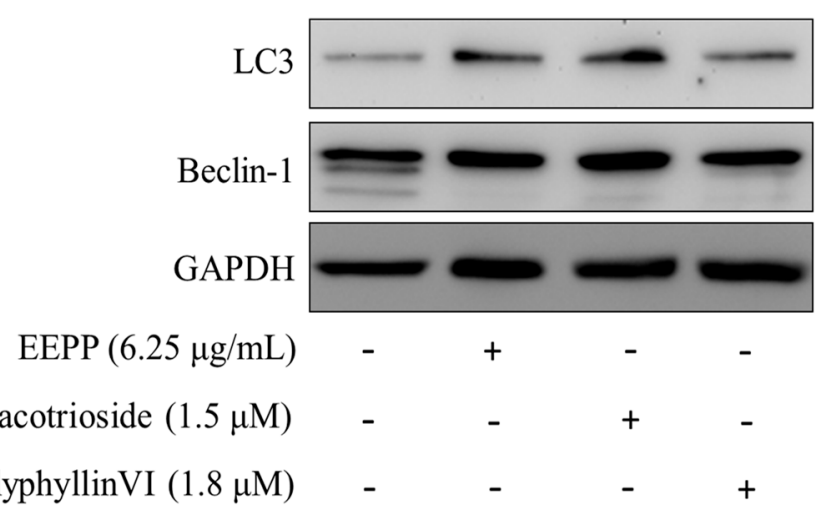

(B)

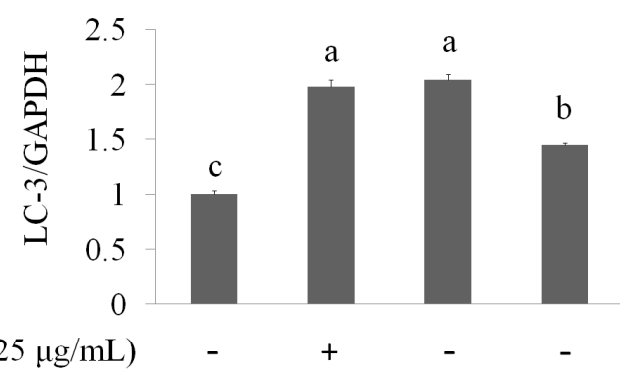

Pennogenin 3-O-beta-chacotrioside $(1.5 \mu \mathrm{M})$

Polyphyllin VI $(1.8 \mu \mathrm{M})$

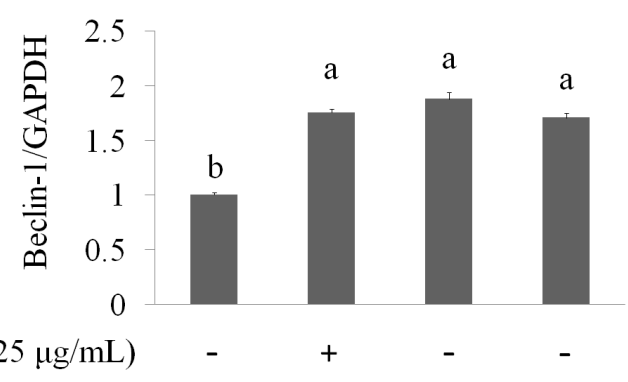

Pennogenin 3-O-beta-chacotrioside $(1.5 \mu \mathrm{M})$

Polyphyllin VI $(1.8 \mu \mathrm{M})$

Figure 8. Elevation of autophagy markers in DLD-1 colorectal carcinoma cells treated with pennogenin 3-O- $\beta$-chacotrioside or polyphyllin VI for $24 \mathrm{~h}$. The concentrations of pennogenin 3-O- $\beta$-chacotrioside and polyphyllin VI were calculated according to EEPP. (A) Pennogenin 3-O- $\beta$-chacotrioside or polyphyllin VI markedly increased the expressions of LC3 and Beclin-1. (B) Quantitative analysis for each protein levels. Data are shown as means $\pm \operatorname{SD}(n=3)$. The significant differences are denoted by different letters $(p<0.05)$. 


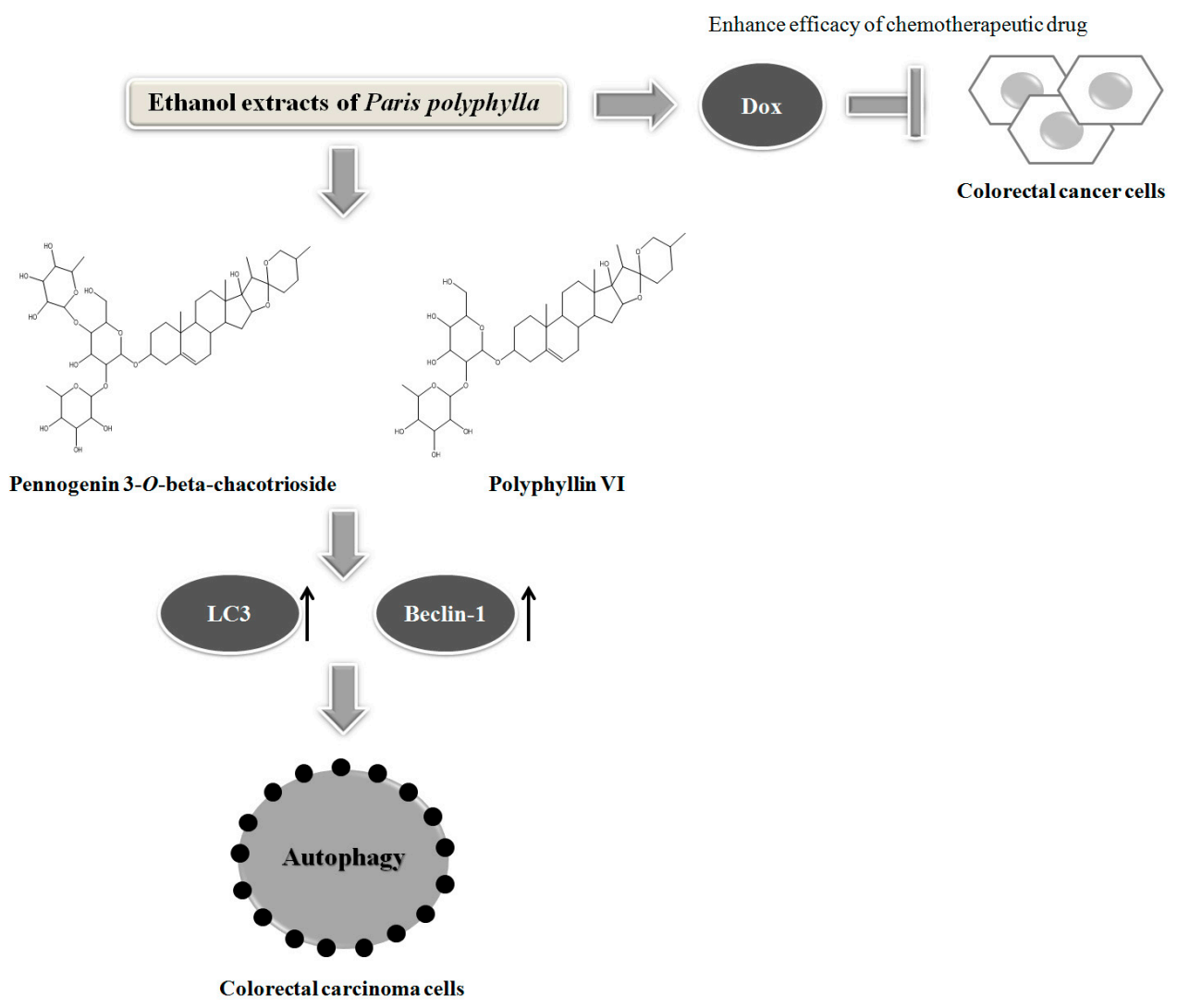

Figure 9. Schematics of the mode of action of Paris polyphylla ethanol extract on DLD-1 colorectal cancer cells.

\section{Materials and Methods}

\subsection{Chemicals}

P. polyphylla was purchased from Taiwan Indigena Botanica Co., Ltd (Taipei, Taiwan), and $10 \mathrm{~g}$ of the herb was extracted with ethanol $(100 \mathrm{~mL})$ three times at room temperature for $24 \mathrm{~h}$. After evaporating the solvents through freeze-drying, a residue was obtained and stored at $-20^{\circ} \mathrm{C}$. Crystal violet, doxorubicin, Propidium iodide (PI), sodium dodecyl sulfate (SDS), Triton X-100, trypsin, and trypan blue were purchased from Sigma Chemical Co. (St. Louis, MO, USA). Fetal bovine serum (FBS) was purchased from Life Technologies (Auckland, New Zealand). Dimethyl sulfoxide was purchased from Wako Pure Chemical Industries (Saitama, Japan). Anti-caspase-3, anti-Bax, anti-Bcl2, anti-p62, anti-p53, anti-LC-3, and anti-GAPDH (Glyceraldehyde 3-phosphate dehydrogenase) antibodies were purchased from Santa Cruz (Santa Cruz, CA, USA). Pennogenin 3-O-beta-chacotrioside was purchased from BioCrickBioTech (Chengdu, Sichuan, China). Polyphyllin VI was purchased from Chem Faces (Wuhan, Hubei, China).

\subsection{Cell Culture}

The human colorectal carcinoma cell line DLD-1 (Bioresource Collection and Research Center, HsinChu, Taiwan) was grown in Dulbecco's modified Eagle's medium (Gibco BRL, Grand Island, NY, USA) containing $2 \mathrm{mM}$ L-glutamine and $1.5 \mathrm{~g} / \mathrm{L}$ sodium bicarbonate, supplemented with $10 \%$ FBS and $2 \%$ penicillin-streptomycin $(10,000 \mathrm{U} / \mathrm{mL}$ penicillin and $10 \mathrm{mg} / \mathrm{mL}$ streptomycin). The cells were cultured in a humidified incubator at $37^{\circ} \mathrm{C}$ under $5 \% \mathrm{CO}_{2}$. 


\subsection{Cell Viability}

The cytotoxic effect of EEPP against DLD-1 cells was measured using a crystal violet staining assay. Cells were seeded on 24 -well plates $\left(3 \times 10^{4}\right.$ cells per well) and treated with various EEPP concentrations for $24 \mathrm{~h}$. The medium was then removed, washed with phosphate-buffered saline (PBS), stained with $2 \mathrm{~g} / \mathrm{L}$ crystal violet in phosphate-buffered formaldehyde for $20 \mathrm{~min}$, and washed with water. The crystal violet bound to the cells was dissolved in $20 \mathrm{~g} / \mathrm{L}$ SDS solution and its absorbance was measured at $600 \mathrm{~nm}$.

\subsection{Cell Cycle}

After $12 \mathrm{~h}$ of exposure to $3.13-12.5 \mu \mathrm{g} / \mathrm{mL}$ EEPP, the medium was aspirated and adherent cells were harvested and centrifuged at $300 \times g$ for $5 \mathrm{~min}$. Cells were washed with PBS, fixed with $700 \mathrm{~mL} / \mathrm{L}$ ice-cold ethanol at $-20{ }^{\circ} \mathrm{C}$ overnight, and then stained with PI at room temperature for $30 \mathrm{~min}$. The cell-cycle distribution was analyzed by flow cytometry using an FACScan-LSR flow cytometer equipped with CellQuest software (BD Biosciences, San Jose, CA, USA) [26].

\subsection{DNA Ladder}

DLD-1 cells were treated with EEPP for $24 \mathrm{~h}$; the cells were then harvested by scraping with a disposable cell lifter, suspended in PBS, and centrifuged for $10 \mathrm{~min}(250 \times \mathrm{g})$ at $4{ }^{\circ} \mathrm{C}$, and the pellet was suspended in $0.1 \mathrm{~mL}$ of hypotonic lysing buffer $(10 \mathrm{mM}$ Tris, pH 7.4; $10 \mathrm{mM}$ EDTA, pH 8.0; 0.5\% Triton $\mathrm{X}-100)$. The cells were incubated for $10 \mathrm{~min}$ at $4{ }^{\circ} \mathrm{C}$, and the resultant lysate was centrifuged for $30 \mathrm{~min}$ $(13,000 \times g)$ at $4{ }^{\circ} \mathrm{C}$. The supernatant, which contained fragmented DNA, was digested and incubated for $1 \mathrm{~h}$ at $37^{\circ} \mathrm{C}$ with $5 \mathrm{mg} / \mathrm{mL}$ RNase A and then incubated for $1.5 \mathrm{~h}$ at $50{ }^{\circ} \mathrm{C}$ with $2.5 \mathrm{mg} / \mathrm{mL}$ proteinase $\mathrm{K}$. DNA was precipitated with 0.5 volume equivalent of $10 \mathrm{M}$ ammonium acetate and 2.5-fold volume equivalent of ethanol at $-20^{\circ} \mathrm{C}$ overnight. The precipitate was centrifuged at $13,000 \times \mathrm{g}$ for $30 \mathrm{~min}$ at $4{ }^{\circ} \mathrm{C}$. The resultant pellet was air-dried and resuspended in $10 \mathrm{mM}$ Tris buffer ( $\mathrm{pH}$ 7.4) containing $1 \mathrm{mM}$ EDTA. An aliquot equivalent to $1 \times 10^{6}$ cells was electrophoresed at $50 \mathrm{~V}$ for $1 \mathrm{~h}$ in $1.5 \%$ agarose gel in $90 \mathrm{mM}$ Tris-borate buffer containing $2 \mathrm{mM}$ EDTA (pH 8.0). After electrophoresis, the gel was stained with ethidium bromide $(0.5 \mu \mathrm{g} / \mathrm{mL})$, and the nucleic acids were visualized with an ultraviolet transilluminator [27].

\subsection{Western Blot}

Cells were rinsed with ice-cold PBS and lysed by RIPA lysis buffer with protease and phosphatase inhibitors for $20 \mathrm{~min}$ on ice. Then, the cells were centrifuged at $12,000 \times \mathrm{g}$ for $10 \mathrm{~min}$ at $4{ }^{\circ} \mathrm{C}$. Protein extracts $(20 \mu \mathrm{g})$ were resolved using SDS polyacrylamide gel electrophoresis (SDS-PAGE; 200 $\mathrm{V}, 45 \mathrm{~min}$ ). The protein bands were electrotransferred to nitrocellulose membranes ( $80 \mathrm{~V}, 120 \mathrm{~min})$. Membranes were then treated with a 5\% enhanced chemiluminescence (ECL) blocking agent (GE Healthcare Bio-Sciences) in saline buffer (TBS-T) containing 0.1\% Tween-20, $10 \mathrm{mM}$ Tris-HCl, $150 \mathrm{mM}$ $\mathrm{NaCl}, 1 \mathrm{mM} \mathrm{CaCl}_{2}$, and $1 \mathrm{mM} \mathrm{MgCl}$ at a $\mathrm{pH}$ of 7.4 for $1 \mathrm{~h}$, and then incubated with the primary antibody overnight at $4{ }^{\circ} \mathrm{C}$. Subsequently, membranes were washed three times in TBS-T and bound antibodies were detected using appropriate horseradish peroxidase-conjugated secondary antibodies, followed by analysis in an ECL plus Western blotting detection system (GE Healthcare Bio-Science) [28].

\subsection{Method of Isolation and Identification of Active Compounds}

Firstly, $50 \mathrm{~g}$ of Paris polyphylla was dissolved in $1 \mathrm{~L}$ of $100 \%$ ethanol and extracted. The extracts were then separated using an ODS (octadecylsilyl) column into different parts. After eluting with different concentrations of methanol, $80 \%$ methanol-treated parts were isolated and detected by HPLC. Pennogenin 3-O-beta-chacotrioside and polyphyllin VI were the two major active compounds in the extracts, identified by LC-MS and NMR. 


\subsection{Statistical Analysis}

Results were expressed as means $\pm \mathrm{SD}$. Comparisons among groups were made using one-way ANOVA. The differences between mean values in all groups were tested through Duncan's multiple-range test (SPSS statistical software package, version 17.0, SPSS, Chicago, IL, USA). A p-value less than 0.05 was considered as a significant difference between means.

\section{Conclusions}

The present study demonstrated that EEPP induced autophagic cell death in colorectal cancer cells and that EEPP combined with Dox might exert a more potent anti-cancer effect against these tumor cells. We suggest that EEPP and its active ingredients pennogenin 3-O-beta-chacotrioside and polyphyllin VI could be further explored as potential candidates for the development of complementary chemotherapy against colorectal cancer.

Author Contributions: L.-T.L. and C.-J.T. performed the design for the overall study and analyzed the data. W.-C.U. performed most of the biochemical assays, and L.-T.L. revised the manuscript. C.-Y.C., B.-H.L., and C.-J.T. were involved in the experimental design and provided significant scientific suggestions and draft corrections before submission. The corresponding author C.-J.T. was responsible for financial resources and funds for the project, supervision of the research activities, and submission of the manuscript. The corresponding author C.-J.T. led the research group and drafted corrections.

Funding: This research work and subsidiary spending were supported by the Taipei Medical University and Taipei Medical University Hospital (108-TMU-TMUH-05), and the Ministry of Science and Technology (MOST-106-2320-B-038-017) (Taiwan, R.O.C.).

Conflicts of Interest: The authors declare no conflicts of interest.

\section{Abbreviations}

EEPP ethanolic extract of Paris polyphylla

LC-3 light chain-3

TCM traditional Chinese medicine

PCD programmed cell death

Dox doxorubicin

\section{References}

1. Man, S.; Gao, W.; Wei, C.; Liu, C. Anticancer drugs from traditional toxic Chinese medicines. Phytother. Res. 2012, 26, 1449-1465. [CrossRef]

2. Zhang, C.; Jia, X.; Bao, J.; Chen, S.; Wang, K.; Zhang, Y.; Li, P.; Wan, J.B.; Su, H.; Wang, Y.; et al. Polyphyllin VII induces apoptosis in Hep G2 cells through ROS-mediated mitochondrial dysfunction and MAPK pathways. BMC Compl. Alt. Med. 2016, 16, 58. [CrossRef]

3. Li, Y.; Gu, J.F; Zou, X.; Wu, J.; Zhang, M.H.; Jiang, J. The anti-lung cancer activities of steroidal saponins of P. polyphylla Smith var. chinensis (Franch.) Hara through enhanced immunostimulation in experimental Lewis tumor-bearing C57BL/6 mice and induction of apoptosis in the A549 cell line. Molecules 2013, 18, 12916-12936. [CrossRef]

4. He, H.; Zheng, L.; Sun, Y.P.; Zhang, G.W.; Yue, Z.G. Steroidal saponins from Paris polyphylla suppress adhesion migration and invasion of human lung cancer A549 cells via down-regulating MMP-2 and MMP-9. Asian Pac. J. Cancer Prev. 2014, 15, 10911-10916. [CrossRef] [PubMed]

5. Li, Y.H.; Sun, Y.; Fan, L.; Zhang, F.; Meng, J.; Han, J. Paris saponin VII inhibits growth of colorectal cancer cells through Ras signaling pathway. Biochem. Pharmacol. 2014, 88, 150-157. [CrossRef] [PubMed]

6. Li, F.R.; Jiao, P.; Yao, S.T.; Sang, H.; Qin, S.C.; Zhang, W.; Zhang, Y.B.; Gao, L.L. Paris polyphylla Smith extract induces apoptosis and activates cancer suppressor gene connexin26 expression. Asian Pac. J. Cancer Prev. 2012, 13, 205-209. [CrossRef] [PubMed]

7. Wang, C.W.; Tai, C.J.; Choong, C.Y.; Lin, Y.C.; Lee, B.H.; Shi, Y.C.; Tai, C.J. Aqueous extract of Paris polyphylla (AEPP) inhibits ovarian cancer via suppression of peroxisome proliferator-activated receptor-gamma coactivator (PGC)-1alpha. Molecules 2016, 21, 727. [CrossRef] 
8. Ernst, E.; Cassileth, B.C. The prevalence of complementary/alternative medicine in cancer: A systematic review. Cancer 1998, 83, 777-782. [CrossRef]

9. Patterson, R.E.; Neuhouser, M.L.; Hedderson, M.M. Types of alternative medicine used by patients with breast, colorectal, or prostate cancer: Predictors, motives, and costs. J. Alternat. Complement. Med. 2002, 8, 477-485. [CrossRef] [PubMed]

10. Richardson, M.A.; Sanders, T.; Palmer, J.L.; Greisinger, A.; Singletary, S.E. Complementary/alternative medicine use in a comprehensive cancer center and the implications for oncology. J. Clin. Oncol. 2000, 18, 2505-2514. [CrossRef]

11. Xu, W.; Towers, A.D.; Li, P.; Collet, J.P. Traditional Chinese medicine in cancer care: Perspectives and experiences of patients and professionals in China. Eur. J. Cancer Care 2006, 15, 397-403. [CrossRef] [PubMed]

12. Qi, F.; Li, A.; Inagaki, Y. Chinese herbal medicines as adjuvant treatment during chemo- or radio-therapy for cancer. Biosci. Trends 2010, 4, 297-307. [PubMed]

13. Youns, M.; Hoheisel, J.D.; Efferth, T. Traditional Chinese Medicines (TCMs) for molecular targeted therapies of tumours. Curr. Drug Discov. Technol. 2010, 7, 37-45. [CrossRef]

14. Coleman, M.P.; Quaresma, M.; Berrino, F. Cancer survival in five continents: A worldwide population-based study (CONCORD). Lancet Oncol. 2008, 9, 730-756. [CrossRef]

15. Cancer Registry Annual Report; Department of Health, Executive Yuan: Taiwan, 2009. Available online: https://www.mohw.gov.tw/lp-137-2.html (accessed on 23 May 2019).

16. De Dosso, S.; Sessa, C.; Saletti, P. Adjuvant therapy for colorectal cancer: Present and perspectives. Cancer Treatment Rev. 2009, 35, 160-166. [CrossRef]

17. Kopetz, S.; Freitas, D.; Calabrich, A.F.C.; Hoff, P.M. Adjuvant chemotherapy for stage II colorectal cancer. Oncology 2008, 22, 260-270.

18. Ye, M.X.; Zhao, Y.L.; Li, Y.; Miao, Q.; Li, Z.K.; Ren, X.L.; Song, L.Q.; Yin, H.; Zhang, J. Curcumin reverses cis-platin resistance and promotes human lung adenocarcinoma A549/DDP cell apoptosis through HIF-1 $\alpha$ and caspase-3 mechanisms. Phytomedicine 2012, 19, 779-787. [CrossRef]

19. Klionsky, D.J.; Emr, S.D. Autophagy as a regulated pathway of cellular degradation. Science 2000, 290, $1717-1721$. [CrossRef]

20. Mizushima, N.; Ohsumi, Y.; Yoshimori, T. Autophagosome formation in mammalian cells. Cell Struct. Funct. 2002, 27, 421-429. [CrossRef]

21. Liu, Y.L.; Yang, P.M.; Shun, C.T.; Wu, M.S.; Weng, J.R.; Chen, C.C. Autophagy potentiates the anti-cancer effects of the histone deacetylase inhibitors in hepatocellular carcinoma. Autophagy 2010, 6, 1057-1065. [CrossRef]

22. Nahimana, A.; Attinger, A.; Aubry, D.; Greaney, P.; Ireson, C.; Thougaard, A.V.; Tjørnelund, J.; Dawson, K.M.; Dupuis, M.; Duchosal, M.A. The NAD biosynthesis inhibitor APO866 has potent antitumor activity against hematologic malignancies. Blood 2009, 113, 3276-3286. [CrossRef]

23. Kim, J.Y.; Cho, T.J.; Woo, B.H.; Choi, K.U.; Lee, C.H.; Ryu, M.H.; Park, H.R. Curcumin-induced autophagy contributes to the decreased survival of oral cancer cells. Arch. Oral Biol. 2012, 57, 1018-1025. [CrossRef]

24. Tai, C.J.; Wang, C.K.; Tai, C.J.; Lin, Y.F.; Lin, C.S.; Jian, J.Y.; Chang, Y.J.; Chang, C.C. Aqueous extract of Solanum nigrum leaves induces autophagy and enhances cytotoxicity of cisplati, doxorubicin, docetaxel, and 5-fluorouracil in human colorectal carcinoma cells. Evid. Based Complement. Alternat. Med. 2013, 2013, 514719. [PubMed]

25. Cummings, J.; Smyth, J.F. DNA topoisomerase I and II as targets for rational design of new anticancer drugs. Ann. Oncol. 1993, 4, 533-543. [CrossRef] [PubMed]

26. Hsu, W.H.; Lee, B.H.; Pan, T.M. Red mold dioscorea-induced G2/M arrest and apoptosis in human oral cancer cells. J. Sci. Food Agric. 2010, 90, 2709-2715. [CrossRef] [PubMed] 
27. Bushell, M.; Poncet, D.; Marissen, W.E.; Flotow, H.; Lloyd, R.E.; Clemens, M.J.; Morley, S.J. Cleavage of polypeptide chain initiation fctor eIF4GI during apoptosis in lymphoma cells: Characterization of an internal fragment generated by caspase-3-mediated cleavage. Cell. Death Differ. 2000, 7, 628-636. [CrossRef] [PubMed]

28. Hsu, W.H.; Lee, B.H.; Huang, Y.C.; Hsu, Y.W.; Pan, T.M. Ankaflavin, a novel Nrf-2 activator for attenuating allergic airway inflammation. Free Radic. Biol. Med. 2012, 53, 1643-1651. [CrossRef]

Sample Availability: Not available.

(C) 2019 by the authors. Licensee MDPI, Basel, Switzerland. This article is an open access article distributed under the terms and conditions of the Creative Commons Attribution (CC BY) license (http://creativecommons.org/licenses/by/4.0/). 